\section{9. 美しい側貎についての一考察}

\section{○吉松 史恵・野田 修司・楠本 修己 野代 悦生・藤田 邦彦・佐藤 通泰 \\ 九歯大 $\cdot$ 歯矯正}

矯正治療を希望する患者の多くが正しい咬合関係だけ でなく，いわゆる“美しい口もと”の審美的改善を期待 している，矯正治療は咬合の改善だけではなく，下顔面 部の側貌に変化をおこすため，演者らは，側貌に対する 現代人の感覚を知り，“美しい顔” の形態的特徵を把握 し，これを治療方針の一助とするため調查を招こなっ た．第35回西日本歯科矯正学会では，上顎正常位で下顎 正常位 (Type B), 下顎後方位 (Type A), 下顎前方位

(Type C) の 3 Type について美しい側貌の評価を行 い, Type B の下口唇の位置が E-lineより-2 mmの側 貎が最も好まれ, Type Cの+8 mmの側貎が最も嫌われ ることを報告した。 今回はさらに, ТуреBの $\angle \mathrm{SNA}$ $5^{\circ}$ 前方に移動させたもの (Type D), $\angle$ SNA を $5^{\circ}$ 後方に移動させたもの (Type E), $\angle \mathrm{SNA}$ を $5^{\circ}$ 後方 に， $\angle \mathrm{SNB}$ を $5^{\circ}$ 前方に移動させたもの（Type F), $\angle \mathrm{SNA}$ を $5^{\circ}$ 前方に, $\angle \mathrm{SNB}$ を $5^{\circ}$ 後方に移動させた あの（Type G）の 4 type を加え前回の結果と合わせて 検討を行ったので報告する. 研究方法：各 type におい て，口唇の位置を， E-line の前方 $8 \mathrm{~mm}$ 加後方 $14 \mathrm{~mm}$ での $2 \mathrm{~mm}$ 間隔で変化させ，12枚の調査用側貎を作製し た．矯正家，学生および一般人の 3 グループに，各 type ご上に連続的に口唇の突出度を变化させたシル エット図を示し，その中から最も美しい側貎，最も嫌わ れる側貌，美しい之思われる範囲を選出させた，次に，

Type $\mathrm{D} \sim \mathrm{G}$ の中から最む美しい側貎, 最も嫌われる側 貎を選出させた，また，前回調査した Type A〜C を加 え, Type $A \sim G$ の中より最も美しい側貎, 最す嫌われ る側貌毛選出させた結果，次のことがわかった。

1. 矯正家，学生および一般人が美しいと思う側貎の タイプは, Straight typeが最む多い傾向にあっ た。次がConvex typeであった。嫌う側貎の夕イ プは, Concave typeであった.

2. 矯正家, 学生および一般人が全タイプの中で最も 美しいと思う側貎は, 上下顎正常位で下口唇の位置 が E-line からー2 mmであった. 最む嫌う側貌は, 上顎後方下顎前方位の $+8 \mathrm{~mm}$ であった。

\section{0. 幼若犬下顎後臼歯の生理的移動に関する組織学的研} 究

\section{○木尾 哲朗・藤田 邦彦・野代 悦生}

九歯大・歯矯正

矯正治療後の咬合を維持・安定させるためには，治療 後，歯がごのように生理的移動するかを知ることが必要 である．この生理的な移動方向については，ヒトやサル では近心方向，ラットや八ムスターの曰歯は遠心方向で あるとされている．1又の場合前方歯は近心方向, 後方 歯は遠心力向とされているが，解明されていない点も多 く，また歯の出龁後の生理的移動についての報告は見当 たらない。

我々は第48・49本学会総会で歯の生理的移動を知る一 助として, 口腔内に装置を装着した実験的研究を報告し た．今回は出䠛後，咬合完成に至るまでの歯の近遠心的 な生理的移動を知るために，生後 $6 〜 8$ ケ月の雑種幼若 犬13頭上成犬 3 頭を用い，下顎左右後臼歯部の歯牙移動 を観察した，歯牙移動の過程で生じる歯槽骨の改造変化 を知るために，一定の間隔で Oxytetracycline，Alizarin Complexon, Calcein を注射し，形成された骨にラ ベリングを行った，幼若犬はラベリング開始後， 2， $3,4 ， 6$ ケ月目に, 成犬は 3 ケ月目に屠殺し, 下顎を 分離後, $10 \%$ 中性ホルマリンで固定し, 通法により非脱 灰切片を作製した. 切片を蛍光顕微鏡で観察後, 同一切 片のマイクロラジオグラムを撮影し，幼若犬と成犬それ ぞれ左右の歯槽骨の変化を観察・検討し以下の結果を得 た.

（1）成犬では，下顎後曰歯は僅かに遠心移動傾向を示す あのがあり，近心移動したすのはなかった。

（2）幼若犬では，一定の移動傾向は認められず，近心移 動を示すすのもあった。

（3）幼若犬では，左右側の歯牙移動方向が異なるものも あり，同側でも一定した方向性は認められなかっ た.

（4）幼若犬では，成犬と比較して移動所見が明確に認め られた。

以上の結果は，幼若犬下顎後臼歯部を用いた歯牙移動 実験を行う際には，生理的な移動方向に一定した方向性 がないことを考慮する必要があると示唆するあのである. 